\title{
Relationships between yield, crop water stress index (CWSI) and transpiration of cowpea (Vigna sinensis L)
}

\author{
AR Sepaskhah *, S llampour \\ Department of Irrigation, Shiraz University, Shiraz, Iran \\ (Received 16 August 1995; accepted 8 March 1996)
}

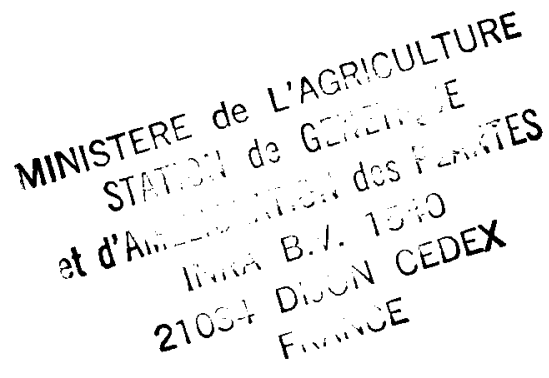

\begin{abstract}
Summary - This research was conducted to correlate the crop water stress index (CWSI) with evapotranspiration $(E T)$, transpiration (T), and yield of cowpea (Vigna sinensis L) in order to apply these relationships to irrigation scheduling and yield production models for this crop. Furthermore, the influence of air and soil parameters in the application of canopy and air temperatures differential ( $T \mathrm{C}-\mathrm{Ta}$ ) for irrigation scheduling of cowpea were investigated. The lower baseline of cowpea during the growing season was (Tc - Ta) $=1.62-0.113$ (VPD) in ${ }^{\circ} \mathrm{C}$ and $\mathrm{mb}$. Its coefficients were smaller than those of most crops reported by other investigators. The upper baseline throughout the growing season was $5.0^{\circ} \mathrm{C}$ which is comparable to that of sugarbeet in the same region. The $k$ value of cowpea in equation $Y \mathrm{U} T=k /\left(e^{\star}-e\right.$ ) (where $\mathrm{Y}$ is the yield and $e^{\star}$, $e$ are the saturated and actual vapor pressures) was $0.041 \mathrm{mb}$ which is similar to that of soybean. It was concluded that the harvest index of cowpea (grain/aerial dry matter), $\mathrm{HI}$, was dependent on transpiration $\left(\mathrm{T}, \mathrm{kg} / \mathrm{ha}\right.$ ) as $\mathrm{HI}=2.37 \times 10^{-4}(\mathrm{~T})^{0.5}$. The quadratic production functions (yield and irrigation water and/or ET) for grain and aerial dry matter of cowpea were obtained. The water sensitivity factors for grain and aerial dry matter of cowpea were 1.01 and 0.53 , respectively, which are less than the factors for soybean grain production. The CWSI was $1.31 \times(1-E T / E T m)$ due to the fact that CWSI was measured and averaged over a portion of the growing season. Therefore, it was concluded that by correcting the CWSI for total growing season the CWSI nearly equals $1-$ ET/ETm. Irrigation timing of cowpea might be determined by a CWSI of 0.106 . Furthermore, it was found that $(T \mathrm{c}-\mathrm{Ta})=0.26 \mathrm{RH}-3.71$ may be applicable for irrigation scheduling of cowpea by canopy and air temperature measurements between $13 \mathrm{~h} 00$ and $14 \mathrm{~h} \mathrm{00}$. Finally, the appropriate equations were given for ET estimation by using canopy and air temperature measurements between $13 \mathrm{~h} 00$ and $14 \mathrm{~h} 00$.
\end{abstract}

water use / evapotranspiration / transpiration / CWSI / Vigna sinensis = cowpea

Résumé - Relation entre le rendement, l'indice de contrainte hydrique sur la culture et la transpiration chez le niébé (Vigna sinensis L). Ce travail était destiné à établir les liens entre lindice de contrainte hydrique d'une culture (CWSI) et l'évapotranspiration, la transpiration et le rendement chez Vigna sinensis $L$ afin d'appliquer cette relation à des modèles de gestion de lirrigation et de prévision du rendement. On a par ailleurs étudié l'influence de paramètres du sol et de l'air sur l'application du différentiel de température entre l'air et le couvert végétal (Tc - Ta) sur la gestion de l'irrigation. La limite inférieure a été : $\left(\mathrm{T}_{\mathrm{c}}-\mathrm{Ta}\right)=1.62-0.113(\mathrm{VPD})$, en ${ }^{\circ} \mathrm{C}$ et $\mathrm{mb}$ pendant la saison de végétation. Ses coefficients étaient plus petits que ceux de la plupart des cultures rapportées par d'autres auteurs. La limite supérieure pendant cette même saison a été $5^{\circ} \mathrm{C}$ ce qui est comparable à celle de la betterave à sucre dans la même. région. La valeur de $k$ dans l'équation $\mathrm{Y} t T=\mathrm{k} / \mathrm{e}^{*}-\mathrm{e}$ ) a été $0,041 \mathrm{mb}$, ce qui est analogue à celle pour le soja. On a conclu que l'indice de récolte du (grain / matière sèche aérienne), $H I$, dépendait de la transpiration $(T, \mathrm{~kg} / \mathrm{ha}) \mathrm{par}: \mathrm{HI}=$ $2,37 / 10^{-4} * T-0.5$. Les fonctions de production (rendement et eau d'irrigation, et/ou ET) pour le grain et la matière

* Correspondence and reprints 
sèche aérienne ont été obtenues. Le facteur de sensibilité à l'eau pour le grain et la matière sèche aérienne ont été 1,01 et 0,53, respectivement, ce qui est inférieur à ceux du soja. Le CWSI a été 1,31 * (1 - ET/ETm), parce qu'il a été mesuré et moyenné sur une partie de la saison végétative. De ce fait, on a conclu que, si on corrige le CWSI pour la saison entière, il doit être proche de $(1-E T / E T m)$. Le calendrier d'irrigation du niébé peut être déterminé par un CWSI de 0,106. De plus on a trouvé que $(\mathrm{Tc}-\mathrm{Ta})=0,26{ }^{*} \mathrm{RH}-3,71$ peut être utilisable pour fixer le calendrier d'irrigation en fonction de mesures de la température du couvert végétal et de l'air entre 13 et $14 \mathrm{~h} 00$. Enfin, les équations adéquates ont été données pour l'estimation de ET en utilisant la température du couvert et de l'air à cette même heure.

utilisation de l'eau / évapotranspiration / transpiration / CWSI

\section{INTRODUCTION}

Production of field crops in arid regions of Iran is dependent on irrigation water. Increasing limitations on water use have motivated the farmers to practice better irrigation management for higher water-use efficiency (yield per unit of water). Yield production models and irrigation scheduling are used in irrigation management.

Water deficit of crops, and the resulting water stress in plants, have an effect on crop evapotranspiration (ET) and crop yield. Water stress in plants can be quantified by the rate of actual ET $(E T a)$ in relation to the rate of maximum ET $(E T p)$. To evaluate the effect of plant water stress on yield decrease, it is necessary to derive the relationships between relative yield decrease $(1-$ $\mathrm{Ya} / \mathrm{Ym})$ and relative ET deficit (1 - ETa/ETp) given by the empirically-derived yield response factor (Ky) (Hanks, 1983) or:

$$
(1-Y a / Y m)=K y(1-E T a / E T p)
$$

in which $Y a$ and $Y m$ are actual and maximum yields, respectively.

The relative ET deficit may be estimated by measurements with infrared thermometry, allowing to measure crop water stress (Jackson et al, 1981; Jackson, 1982; Pinter and Reginato, 1982). It was called the crop water stress index (CWSI) and defined by Jackson et al (1981) as:

$$
\mathrm{CWSI}=1-\mathrm{ETa} / \mathrm{ETp}
$$

They also presented a theoretical method for calculating the CWSI. The index was also quantified experimentally by Idso et al (1981) with canopy-air temperature differentials $(T \mathrm{c}-T \mathrm{a}$ ) and vapor pressure deficit (VPD).

The estimated values of CWSI by the methods of Idso et al (1981) and Jackson et al (1981) were used to derive ETa/ETp and yield relation- ships for alfalfa and sweet lime by Abdul-Jabbar et al (1985) and Sepaskhah and Kashefipour (1994), respectively.

CWSI and canopy air temperature differential ( $T \mathrm{C}-\mathrm{Ta}$ ) have been used for irrigation scheduling (Stegman and Soderlund, 1989; Geiser et al, 1982 ) of wheat and cotton. Other environmental parameters, ie air relative humidity, net radiation and soil water, are effective in application of $(T \mathrm{c}-T \mathrm{a})$ for irrigation scheduling (Geiser et al, 1982).

As ETa combines soil evaporation and plant transpiration, it may be necessary to identify each of these components because dry matter elaborated by crop photosynthesis is only directly linked to the second component. In this way, de Wit (1958) showed that in an arid climate with high radiation total dry matter production in the field or in a greenhouse ( $Y t$ ) was linearly related to the seasonal transpiration $(\mathrm{T})$ as follows:

$$
\mathrm{Y} t / \mathrm{T}=\mathrm{m} / \mathrm{EO}_{\mathrm{O}}
$$

in which Eo is the daily average evaporation rate from open water and $m$ is a constant which depends on the plant species. Arkley (1963) and Bierhuizen and Slatyer (1965) proposed the following equation:

$$
Y t / T=k /\left(e^{*}-e\right)
$$

in which $e^{\star}$ and $e$ are the saturated vapor pressure and actual vapor pressure $(\mathrm{mb})$ and $\mathrm{k}$ is a constant $(\mathrm{mb})$ which depends on the plant species. Similarly, Tanner (1981) indicated that potato yields in different years were related to the ratio of transpiration and vapor pressure deficit. Different values of $k$ in eq (4) for various crops were given by Tanner and Sinclair (1983).

This research was conducted to correlate these various components (namely CWSI, ET and $T$ ) to the yield of cowpea in order to apply these relationships in irrigation scheduling and to 
develop simple yield production models for this crop. Furthermore, the influence of air and soil parameters in the application of $(T \mathrm{C}-\mathrm{Ta})$ for irrigation scheduling of cowpea was investigated.

\section{MATERIALS AND METHODS}

The experiment was conducted at the Badjgah Agricultural Experiment Station located $16 \mathrm{~km}$ north of Shiraz, Iran. The soil type at the site was a Daneshkadeh clay loam (Calcixerollic Xerochrept). Cowpea cultivar '29005' was planted on 13 May 1990 in rows $60 \mathrm{~cm}$ apart and with a distance of about $9 \mathrm{~cm}$ between each plant. Ammonium phosphate and urea were applied to the field before planting at a rate of $78 \mathrm{~kg} / \mathrm{ha} \mathrm{N}$ (due to low nitrogen fixation at the early growth stages) and $42 \mathrm{~kg} / \mathrm{ha} P$. Before the first irrigation, the soil water content over a depth of $0-120 \mathrm{~cm}$ was measured by neutron probe at $15 \mathrm{~cm}$ depth intervals. Following planting, the field was irrigated four times between 13 May and 5 June by two overlapping sprinkler laterals $12 \mathrm{~m}$ apart with a sprinkler spacing of $12 \mathrm{~m}$ on each lateral. The average sprinkler discharge was $2.5 \mathrm{~m}^{3} / \mathrm{h}$ over $144 \mathrm{~m}^{2}$. The total amount of water applied in this period was $159.4 \mathrm{~mm}$. When the plants were at the four leaf stage, subsequent irrigations were applied using a 60-m sprinkler line source (Hanks et al, 1976) to obtain a gradient in applied water with an irrigation interval of seven days (fig 1). The sprinkler spacing on the line was $6 \mathrm{~m}$. The water application pattern was not symmetric with respect to the line source, therefore the number of irrigation treatments were unequal on the right and left sides. By dividing up the land into five and six stripes parallel to the source line on the left and right, respectively, five and six irrigation treatments on the left and right sides were established. These were designated as treatments 1 to 5 on the left and 1 to 6 ( $6=$ well-stressed treatment) on the right. The amount of water applied decreased with increasing distance perpendicular to the line. The operation period of the line source was determined by the amount of irrigation treatment 1 . The amount of irrigation water for treatment 1 was determined by calculating the difference between soil water before irrigation and soil field capacity at a depth of $1.2 \mathrm{~m}$. The system was operated in the early morning (predawn) when there was little or no wind.

Catch cans were installed across the field in four rows perpendicular to the line source with a spacing of $1.0 \mathrm{~m}$ (fig 1). Every three rows of plants at each side of line source were considered as an irrigation treatment. Along the catchment cans, in each irrigation treatment one neutron tube was installed at a depth of $1.2 \mathrm{~m}$ (fig 1). The soil water content before each irrigation was measured every $15 \mathrm{~cm}$ to a depth of $1.2 \mathrm{~m}$ by a neutron probe.

In order to measure evaporation independently, six microlysimeters were located between crop rows in two rows perpendicular to the line source in only three irrigation treatments in each side of the line source (fig 1). The microlysimeters were cylinders $600 \mathrm{~mm}$ long and $100 \mathrm{~mm}$ in diameter with a 2-mm-thick wall. They were made of PVC tubes with a perforated bottom. The average evaporation rate during the irrigation intervals was measured by weighing the microlysimeter after an irrigation and before the next irrigation with no drainage at the bottom of the tubes.

Evapotranspiration (ET) was determined from the water balance equation:

$$
\mathrm{ET}=I+R-D \pm \Delta S
$$

in which $l$ is the amount of irrigation in $\mathrm{mm}, R$ is the rainfall in $\mathrm{mm}, D$ is the deep percolation in $\mathrm{mm}$, and $\Delta S$ is the change in soil water content in $\mathrm{mm}$. The amount of rain during the growing season was negligible.

The measured soil water contents at a depth of 1.2 $m$ indicated that the soil moisture was higher than the soil field capacity only in the first and second irrigation plots on the right hand side of line source (fig 1). Therefore, their deep percolations were estimated by assuming a unit hydraulic gradient (vertical soil water flux $=K(\theta)$ ) and using the following equation:

$$
K(\theta)=2.72\left(10^{-19}\right) \mathrm{e}^{1.1 \theta}
$$

in which $K(\theta)$ is the unsaturated hydraulic conductivity $(\mathrm{cm} /$ day) as a function of volumetric soil water content $(\theta, \%)$. This equation yields reasonable hydraulic conductivity values for the observed range of $\theta$.

The difference between ET (measured by the water balance equation) and $E$ (measured by six

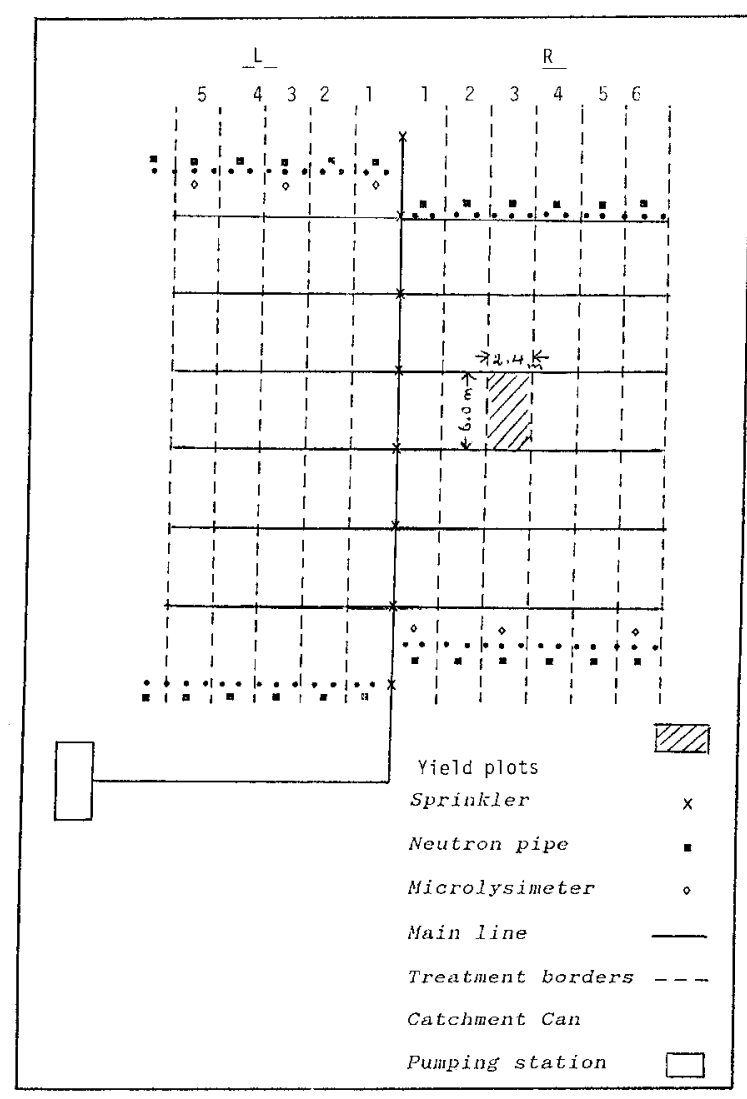

Fig 1. The experimental layout. 
microlysimeters) was considered as transpiration $(T)$. For the remaining five irrigation treatments, the seasonal $E$ was estimated by assuming a linear decrease of evaporation as a function of distance from the sprinkler line source.

The CWSI was measured on canopies of the different irrigation treatments on both sides of the line source. Canopy temperatures $(T \mathrm{c})$ were measured on 23 June 1990 and later on with an infrared thermometer with 7.5 and 14 micrometer band filters, and a $2^{\circ}$ field of view that was calibrated for use in high ambient temperature. The canopy temperatures (Tc) at the middle of treatment stripes at the lower and upper parts of the experimental site were taken with the thermometer pointed obliquely towards the crop (about $45^{\circ}$ from horizontal and a distance of $35 \mathrm{~cm}$ from rows) and from all four cardinal directions, N, E, S and W. At the same time, the air temperature and relative humidity were measured by a glass thermometer and a dial gauge-type psychrometer held at a height of $1.2 \mathrm{~m}$ above the soil in a naturally aerated cardboard shield. The canopy and air temperatures and VPD measurements for the lower baseline determination were carried out on two days in June, three days in July and three days in August (11-12 measurements each day) from $7 \mathrm{~h} 00$ to $14 \mathrm{~h} 00$ at $30-60 \mathrm{~min}$ intervals (Idso et al, 1981), during the period in which the stomata were open. The $T \mathrm{c}, \mathrm{Ta}$ and $\mathrm{RH}$ for upper baseline were measured on dry irrigation treatment (well stressed) between $13 \mathrm{~h} 00$ and $14 \mathrm{~h} 00$ on 16 days spread over the growing season (June to late August). On the same days, $\mathrm{Tc}, \mathrm{Ta}$ and $\mathrm{RH}$ were measured between $13 \mathrm{~h} 00$ and $14 \mathrm{~h} 00$ for CWSI calculation on the various irrigation treatments. The CWSI was outlined by Idso et al (1981) as shown in figure 2 and the following equation:

$$
\begin{aligned}
\mathrm{CWSI}= & {\left[(T \mathrm{c}-T \mathrm{a})-(T \mathrm{c}-T \mathrm{a})_{1}\right] /\left[(T \mathrm{C}-T \mathrm{a})_{\mathrm{u}}\right.} \\
& \left.-(T \mathrm{c}-T \mathrm{a})_{1}\right]
\end{aligned}
$$

in which $(T \mathrm{C}-T \mathrm{a})$ is the measured $(T \mathrm{C}-T \mathrm{a})$, and $\left(T_{\mathrm{C}}\right.$ $-T a)_{\mid}$and $(T c-T a)_{u}$ are the lower and upper baseline values corresponding to the measured value of VPD.

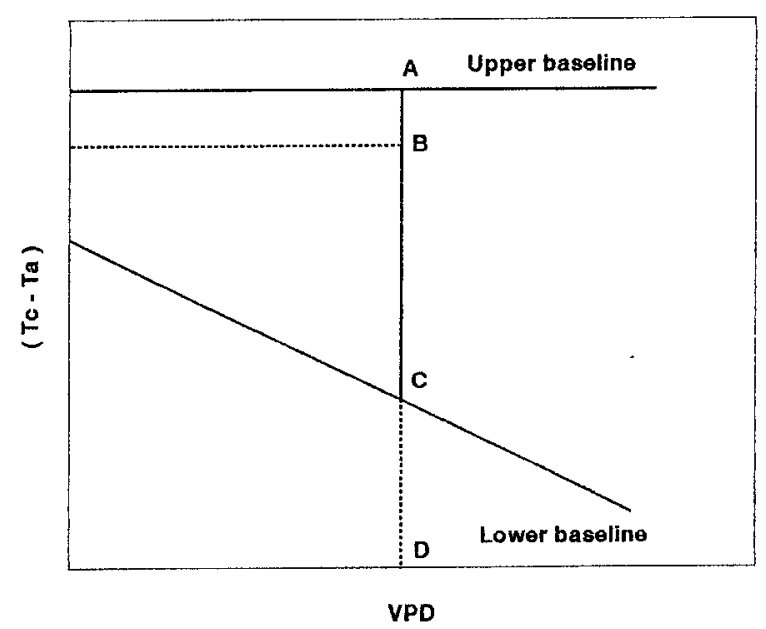

Fig 2. Calculation scheme of CWSI. $A C=(T C-T a)_{u}-$ $(T C-T a), B C=(T C-T a)-(T C-T a), C W S I=B C / A C$.
The hourly solar radiation (Rs) was measured by a solar radiometer at a near by weather station. Then the proposed linear equations $(R \mathrm{n}=a+b R \mathrm{~s})$ by AbdulJabbar et al (1985) for wet, intermediate and dry irrigation treatments were used to estimate the hourly net radiation $(R \mathrm{n})$ between $13 \mathrm{~h} 00$ and $14 \mathrm{~h} 00$ for 10 days from 23 June to 8 September 1990. At the same dates and time of day, the soil water content was measured at $15 \mathrm{~cm}$ intervals to a depth of $1.2 \mathrm{~m}$ with a neutron probe.

The grain yield was determined on 17-19 September 1990 on five regular plots of $2.4 \times 6.0 \mathrm{~m}^{2}$ per irrigation treatment at the left and right sides of the line source. The dry vine yield was also determined on the same plots.

\section{RESULTS AND DISCUSSION}

CWSI data will be presented first, then a second section will focus mainly on table I. A third part will be devoted to yield against various components and a last part will discuss the relations between these components. At the end, we will conclude with some comments regarding the application to irrigation.

\section{Crop water stress index}

The relationship between canopy and air temperature differential ( $T \mathrm{C}-T \mathrm{a}$ ) and air VPD of the well-watered treatment is shown on figure 3 as the lower baseline. It was described by the following equation which was obtained by a least squares procedure:

$$
\begin{aligned}
& (T \mathrm{c}-T \mathrm{a})=1.62-0.113(\mathrm{VPD}) \\
& r=-0.56, \mathrm{df}=88, P<0.01
\end{aligned}
$$

in which $(T c-T a)$ is in ${ }^{\circ} \mathrm{C}$ and VPD is in $\mathrm{mb}$. The data of ( $T \mathrm{C}-T \mathrm{a})$ and VPD obtained on eight days from 23 June to 17 August 1990 have been used to establish the lower baseline (eq 8). Therefore, the generality of eq [8] may not be restricted. Figure 3 indicated that the canopy temperatures are from 0.0 to $7.0^{\circ} \mathrm{C}$ cooler than the air temperature over the VPD range of 25 to $60 \mathrm{mb}$. The slope and intercept of eq [8] were lower than those reported for corn, tomatoes, potatoes, rice, sugarbeet and a different species of cowpea (Idso, 1982; Sepaskhah et al, 1987). The differences could be attributed to the physiological differences between plant species.

The average values of ( $T \mathrm{c}-\mathrm{Ta}$ ) for upper baseline (well-stressed plants of treatment 6) 


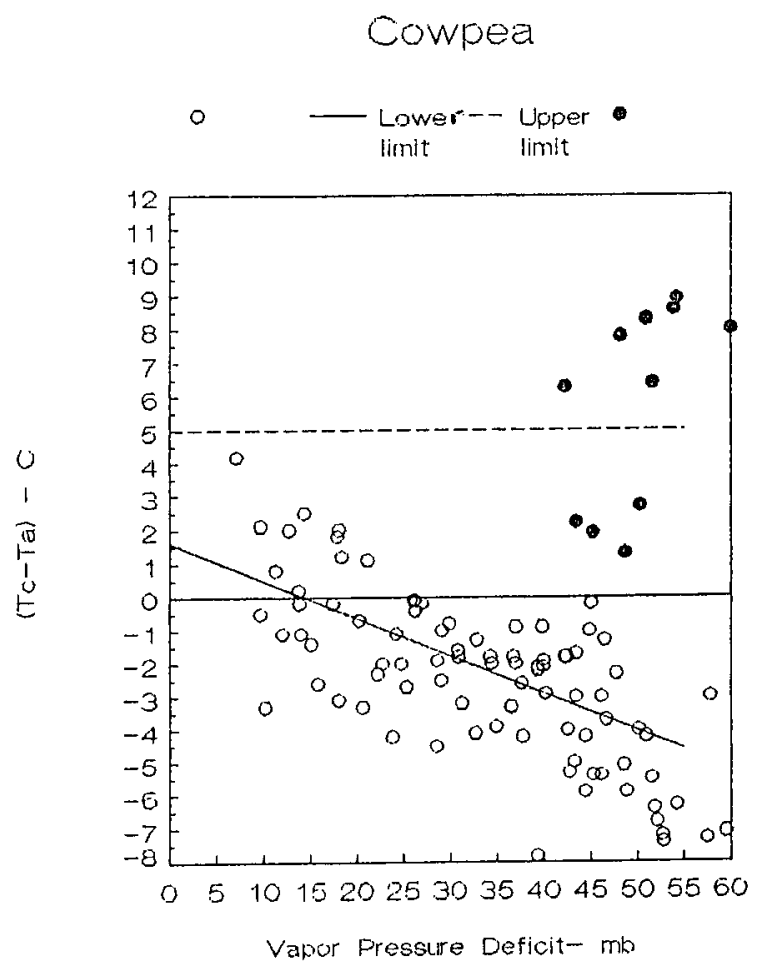

Fig 3. The relationship between canopy and air temperature differential and vapor pressure deficit (VPD) for cowpea (solid line = lower baseline, dashed line = upper baseline).

were 2.6 and $8.1^{\circ} \mathrm{C}$ in July and August, respectively and $5.0^{\circ} \mathrm{C}$ for the growing season. The upper baseline value may be greatly influenced by microclimatic parameters such as $R \mathrm{n}$ and wind speed so that large deviations between days may be expected. The upper baseline of cowpea was almost the same as that of sugarbeet (4.2) as reported by Sepaskhah et al (1988) in the same region.

CWSI was calculated as the ratio of the deviation of the measured ( $T \mathrm{c}-\mathrm{Ta}$ ) from the lower baseline (eq 8 ) to the range between the lower and upper baselines $\left(5.0^{\circ} \mathrm{C}\right)$ at a given VPD (Idso et al, 1981). The results of average CWSI during the treatment period for different irrigation treatments are shown in table I. CWSI increased at drier irrigation treatments. However, due to the variation of data points around the baselines, the CWSI calculated for treatment 6 at the left side of line source was 1.2 which is greater than 1 (the maximum possible CWSI).

\section{Main results}

The grain and total aerial dry yields from the various irrigation treatments at both sides of line source are depicted in table I. The results indicated that the highest grain and aerial dry yields were produced by irrigation treatment 1 on the right side and decreased towards the drier irrigation treatments.

Evapotranspiration (ET), transpiration (T) and evaporation $(E)$ at the different irrigation treatments are shown in table I. The maximum ET, $(E T m)$ resulted from irrigation treatment 1 on the right side and decreased towards the drier irrigation treatments. The maximum $\mathrm{T},(\mathrm{Tm})$ was obtained from irrigation levels 1 and 2 on the right side and decreased towards the drier irrigation treatments.

In general, the crop water used was rather high due to the climatic conditions of the region. The seasonal reference potential evapotranspiration of the region was about $957 \mathrm{~mm}$ according to the FAO modified Penman method (Doorenbos and Pruitt, 1977). The seasonal evaporation (E) was higher at the wet irrigation treatment and decreased towards the drier treatment. In general, the ET loss like $E$ was very high: about $50 \%$ for wet treatments and up to $60 \%$ for the dry case.

The ratio of grain to aerial dry matter (harvest index), $\mathrm{HI}$ decreased linearly with CWSI (fig 4) as follows:

$$
\begin{aligned}
& \mathrm{HI}=0.47-0.18(\mathrm{CWSI}), \\
& \mathrm{df}=9, \mathrm{R}^{2}=0.96, P<0.01
\end{aligned}
$$

This indicated that water stress is acting separately on aerial dry matter and grain production.

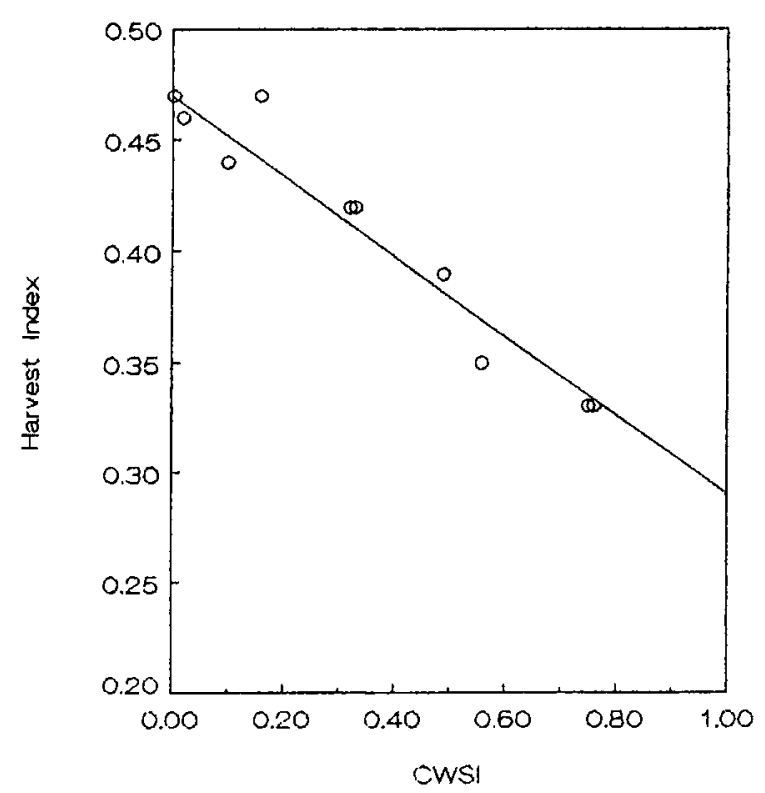

Fig 4. The relationship between harvest index and CWSI. 
Table I. The amounts of grain $(Y)$ and aerial dry matter yields $(Y t)$, harvest index $(H I)$, evapotranspiration (ET), evaporation $(E)$, transpiration $(T)$, irrigation water $(I)$ and crop water stress index (CWSI) of cowpea at different irrigation treatments.

\begin{tabular}{|c|c|c|c|c|c|c|c|c|c|}
\hline \multicolumn{2}{|c|}{$\begin{array}{l}\text { Irrigation } \\
\text { treatments }\end{array}$} & $\begin{array}{c}Y t \\
(k g / h a)\end{array}$ & $\begin{array}{c}Y \\
(k g / h a)\end{array}$ & $H I$ & $\begin{array}{r}E T \\
(\mathrm{~cm})\end{array}$ & $\underset{(\mathrm{cm})}{\mathrm{E}}$ & $\begin{array}{c}\mathrm{T} \\
(\mathrm{cm})\end{array}$ & $\begin{array}{c}1 \\
(\mathrm{~cm})\end{array}$ & CWSI \\
\hline \multirow[t]{6}{*}{ Right } & 1 & 5913 & 2793 & 0.47 & 86.4 & 45.9 & 41.9 & 99.7 & 0.004 \\
\hline & $2^{*}$ & 5300 & 2507 & 0.47 & 82.2 & 40.3 & 41.9 & 86.2 & 0.16 \\
\hline & 3 & 4926 & 2069 & 0.42 & 71.1 & 36.9 & 34.2 & 67.0 & 0.32 \\
\hline & $4^{*}$ & 4862 & 1702 & 0.35 & 51.5 & 31.3 & 20.2 & 47.4 & 0.56 \\
\hline & $5^{\star}$ & 3768 & 1234 & 0.33 & 52.1 & 29.3 & 22.8 & 44.2 & 0.76 \\
\hline & 6 & 3518 & 962 & 0.27 & 43.7 & 26.3 & 17.4 & 37.2 & $1.20^{\star *}$ \\
\hline \multirow[t]{5}{*}{ Left } & 1 & 5073 & 2338 & 0.46 & 72.9 & 36.2 & 36.7 & 69.3 & 0.02 \\
\hline & $2^{*}$ & 5186 & 2288 & 0.44 & 61.4 & 32.0 & 29.4 & 59.1 & 0.10 \\
\hline & 3 & 4863 & 2050 & 0.42 & 57.3 & 30.2 & 27.1 & 54.9 & 0.33 \\
\hline & $4^{\star}$ & 5048 & 1981 & 0.39 & 50.1 & 29.0 & 21.1 & 46.3 & 0.49 \\
\hline & 5 & 4215 & 1380 & 0.33 & 42.5 & 24.0 & 18.5 & 39.6 & 0.75 \\
\hline
\end{tabular}

* The values of $E$ were estimated for these treatments. ${ }^{* *}$ Omitted in regression analyses of non-corrected CWSI.

\section{Analyses of yield}

The relationships between cowpea grain $(Y)$ and aerial dry matter yields $(Y t)$ and the amount of irrigation water (production functions) by least squares fitting (fig 5 ) are as follows:

$$
\begin{aligned}
& Y=-1324+83.4(I)-0.43(I)^{2}, \\
& \mathrm{df}=9, R^{2}=0.869, P<0.01
\end{aligned}
$$

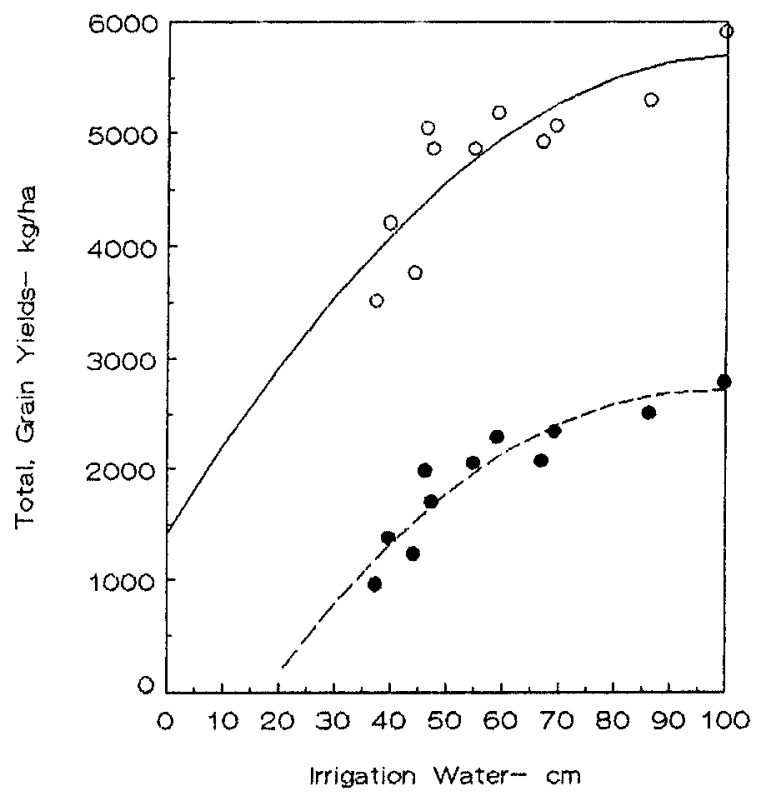

Fig 5. The relationships between total and grain yields and irrigation water.

$$
\begin{aligned}
& Y \mathrm{t}=1416+83.8(I)-0.41\left(I^{2}\right. \\
& \mathrm{df}=9, R^{2}=0.612, P<0.01
\end{aligned}
$$

The maximum grain $(2720 \mathrm{~kg} / \mathrm{ha})$ and aerial dry matter yields (5698 $\mathrm{kg} / \mathrm{ha}$ ) resulted from 97.0 and $102.2 \mathrm{~cm}$ of applied water respectively. In eq [11] when $I=0, Y t$ is equal to $1416 \mathrm{~kg} / \mathrm{ha}$. This indicated that $1416 \mathrm{~kg} / \mathrm{ha}$ aerial dry matter of cowpea could be produced with consumption of the soil water storage. From eq [10] it is clear that the grain yield is equal to zero at $I=17.4 \mathrm{~cm}$. Therefore, this is the estimated threshold irrigation level for grain production.

The relationships between grain and aerial dry matter yields and ET by least squares fitting (fig 6) are as follows:

$$
\begin{aligned}
& Y=-1734+87.8(\mathrm{ET})-0.43(\mathrm{ET})^{2} \\
& \mathrm{df}=9, R^{2}=0.789, P<0.01 \\
& Y t=120.6(\mathrm{ET})-0.66(\mathrm{ET})^{2} \\
& \mathrm{df}=9, R^{2}=0.993, P<0.01
\end{aligned}
$$

The maximum grain $(2748 \mathrm{~kg} / \mathrm{ha})$ and aerial dry matter yields $(5509 \mathrm{~kg} / \mathrm{ha}$ ) resulted from 102.1 and $91.4 \mathrm{~cm}$ of ET, respectively. Eq [12] indicated that the threshold ET of $22.2 \mathrm{~cm}$ is needed for grain yield production. A quite different threshold of $E T$ for soybean grain production $(12.9 \mathrm{~cm})$ was reported by Stegman (1989). This 
may be due to a climatic different value of potential ET.

The relationships between grain and aerial dry matter yields reduction and relative ET reduction by least squares fitting are as follows (fig 7):

$$
\begin{aligned}
& (1-Y / Y m)=1.01(1-\mathrm{ET} / \mathrm{ET} m) \\
& \mathrm{df}=9, R^{2}=0.764, P<0.01 \\
& (1-\mathrm{Tt} / \mathrm{Ytm})=0.53(1-\mathrm{ET} / \mathrm{ETm}) \\
& \mathrm{df}=9, R^{2}=0.617, P<0.01
\end{aligned}
$$

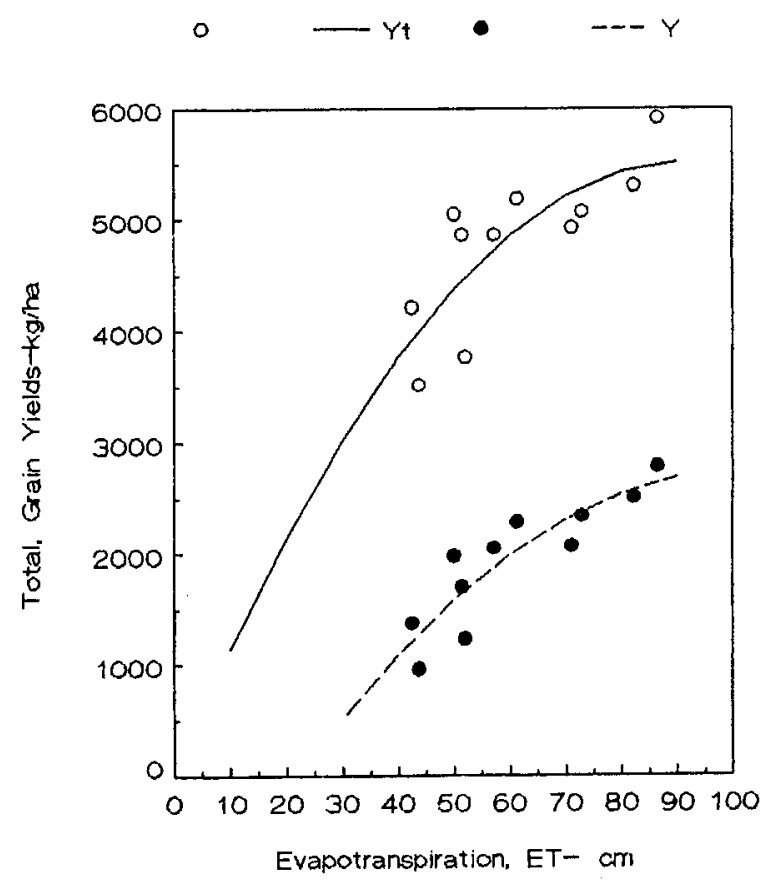

Fig 6. The relationships between total and grain yields and seasonal evapotranspiration.

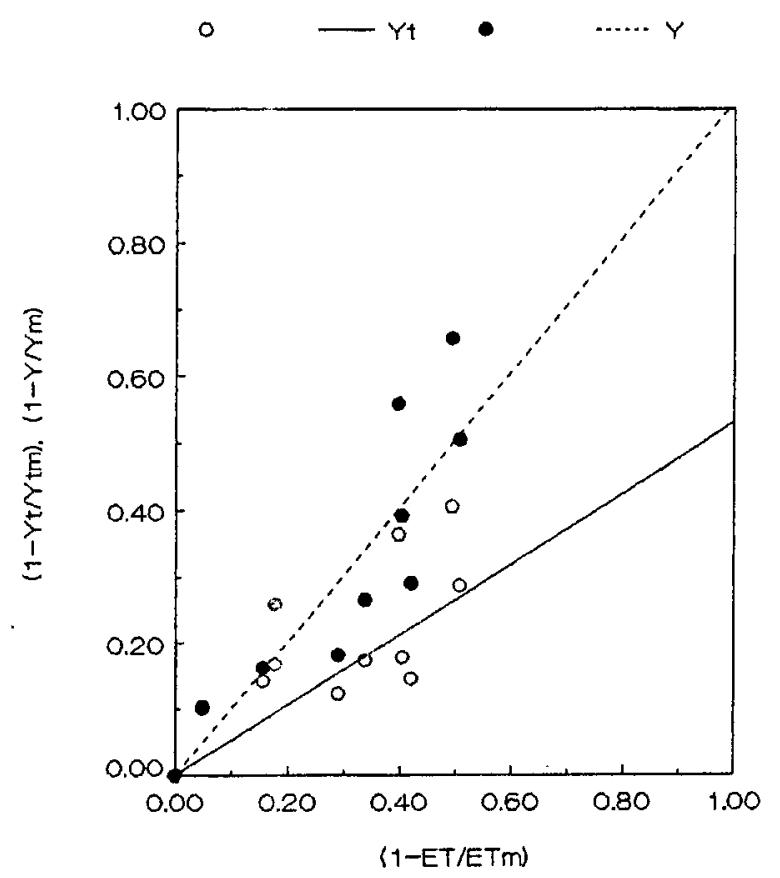

Fig 7. The relationships between $(1-\gamma / Y \mathrm{Hm}),(1-Y / Y \mathrm{~m})$ and $(1-E T / E T m)$.
The coefficients of 0.53 and 1.01 are called water sensitivity factors (Doorenbos and Kassam, 1979). It is clear that aerial dry matter production of cowpea is less sensitive than grain yield to water. Furthermore, the factor of sensitivity for grain production of cowpea is found to be less than reported for soybean (1.5) (Stegman, 1989).

The relationships between grain ( $t / h a)$ and aerial dry matter yields (t/ha) and CWSI of cowpea by least squares fitting are as follows (fig 8):

$$
\begin{aligned}
& Y=2.61-1.64 \mathrm{CWSI} \\
& \mathrm{df}=8, R^{2}=0.911, P<0.01 \\
& Y t=5.54-1.78 \mathrm{CWSI} \\
& \mathrm{df}=8, R^{2}=0.741, P<0.01
\end{aligned}
$$

The slope of eq [16] was smaller than those of alfalfa (3.15), cotton (2.96) and cotton lint (2.67) as reported by Abdul-Jabbar et al (1985); Howell et al (1984) and Robert et al (1985), respectively. Therefore, the results indicated that the yield of cowpea decreased at a slower rate than other crops as water stress increased.

A relationship between the aerial dry matter $(Y t)$ and transpiration $(T)$ has been given by Arkley (1963) as eq [4]. Using the $Y t$ and $T$ data in table I, the $k$ value was determined as $0.041 \pm$ $0.003 \mathrm{mb}$. The values of $k$ for corn, sorghum, tomatoes, alfalfa and soybean obtained by Tanner and Sinclair (1983) were 0.118, 0.188, $0.055,0.05$ and $0.041 \mathrm{mb}$, respectively. The

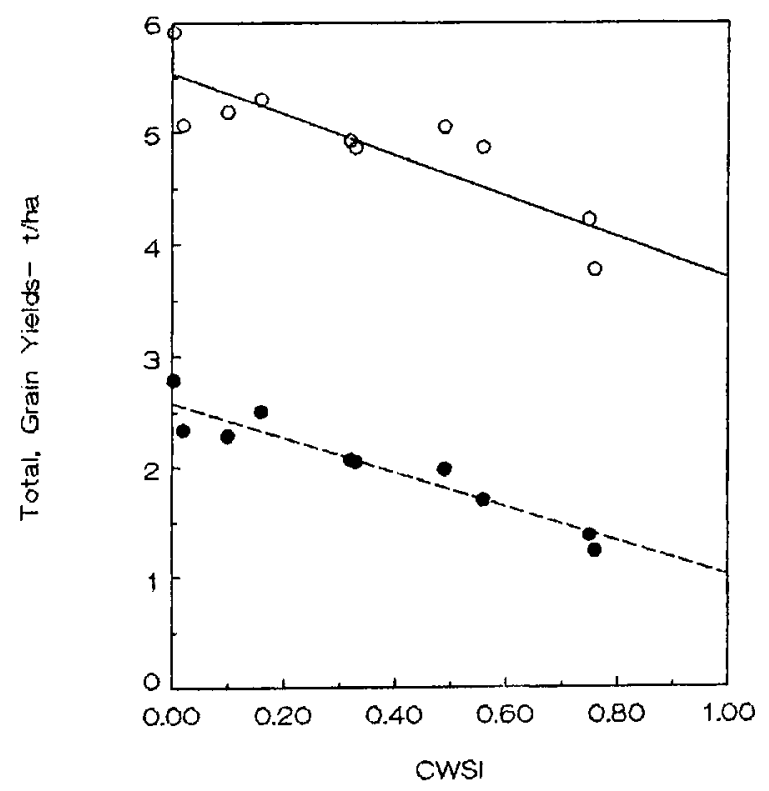

Fig 8. The relationships between total and grain yields and CWSI. 
value of $k$ for cowpea is equal to that of soybean and this is probably because they might be physiologically similar. Eq [4] with the $k$ value of 0.041 $\mathrm{mb}$, average value of $\left(e^{\star}-e\right)$ and transpiration during the growing season can be used to predict the aerial dry matter production of cowpea. Then, by an appropriate value of the harvest index (grain/aerial dry matter), $\mathrm{HI}$, the grain yield might be predicted. The $\mathrm{HI}$ was not a constant and decreased with decreasing $\mathrm{T}$ ( $\mathrm{kg} / \mathrm{ha}$ ) (table I). Their relationship was obtained by the regression method as follows (fig 9):

$$
\begin{aligned}
& \mathrm{HI}=2.37 \times\left(10^{-4}\right)(\mathrm{T})^{0.5} \\
& \mathrm{df}=9, R^{2}=0.81, P<0.01
\end{aligned}
$$

Therefore, the equation for cowpea grain yield $(Y, \mathrm{~kg} / \mathrm{ha})$ prediction can be written:

$$
Y=2.37 \times\left(10^{-4}\right)\left[K /\left(e^{*}-e\right)\right](T)^{1.5}
$$

So, by estimation of seasonal transpiration ( $\mathrm{T})$, the grain yield $(Y)$ may be estimated.

\section{Interrelations between components}

The obtained relationship between CWSI and (1-ET/ETm) by least squares fitting is as follows (fig 10):

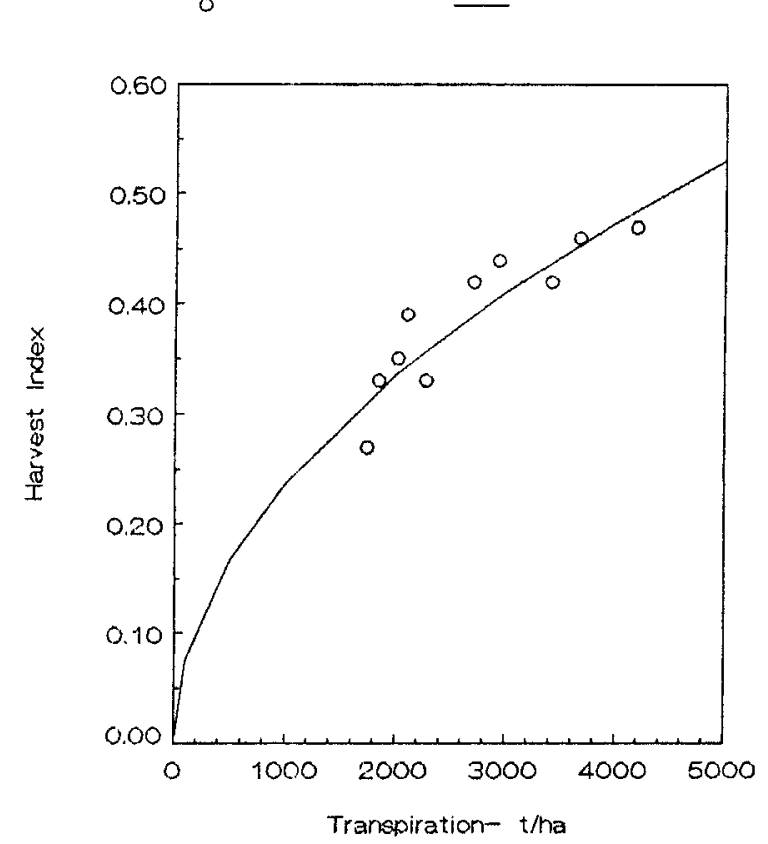

Fig 9. The relationship between harvest index and seasonal transpiration.

$$
\begin{aligned}
& \mathrm{CWSI}=1.31(1-\mathrm{ET} / \mathrm{ETm}) \\
& \mathrm{df}=8, R^{2}=0.892, P<0.01
\end{aligned}
$$

According to the theoretical analysis of Jackson et al (1981) the coefficient of eq [20] should be 1 if ET is determined for a crop surface with full cover. The obtained relationship between CWSI and $(1-\mathrm{T} / \mathrm{Tm})$ by least squares fitting is as follows (fig 11):

$$
\begin{aligned}
& \mathrm{CWSI}=1.16(1-\mathrm{T} / \mathrm{Tm}) \\
& \mathrm{df}=8, R^{2}=0.901, P<0.01
\end{aligned}
$$

The coefficient of eq [21] for transpiration reduction is also greater than 1 . Therefore, it is indicated that the measured average CWSI during the period of irrigation treatments was higher than that for the total growing season. This might be due to the fact that the irrigation treatments were imposed only during $76 \%$ of the total growing season while ET was determined for the whole growing season. Therefore, the average CWSI for the whole growing season should be smaller than the measured average during $76 \%$ of the total growing season. However, it should be mentioned that the relationships between CWSI, $(1-E T / E T m){ }^{*}$ and $(1-T / T m){ }^{*}$ for the irrigation treatment period by least squares fitting are as follows (figs 10 and 11):

$$
\begin{aligned}
& \text { CWSI }=1.0(1-\mathrm{ET} / \mathrm{ETm})^{\star} \\
& \mathrm{df}=8, R^{2}=0.892, P<0.01
\end{aligned}
$$

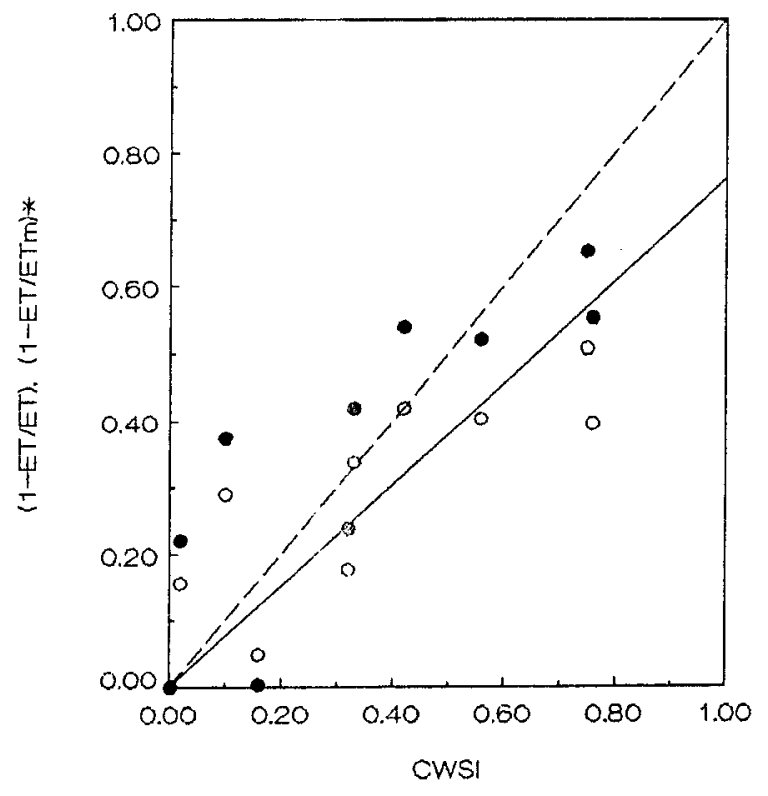

Fig 10. The relationships between $(1-E T / E T m)$, corrected $(1-\mathrm{ET} / \mathrm{ETm})\left(^{*}\right)$ and CWSI. 


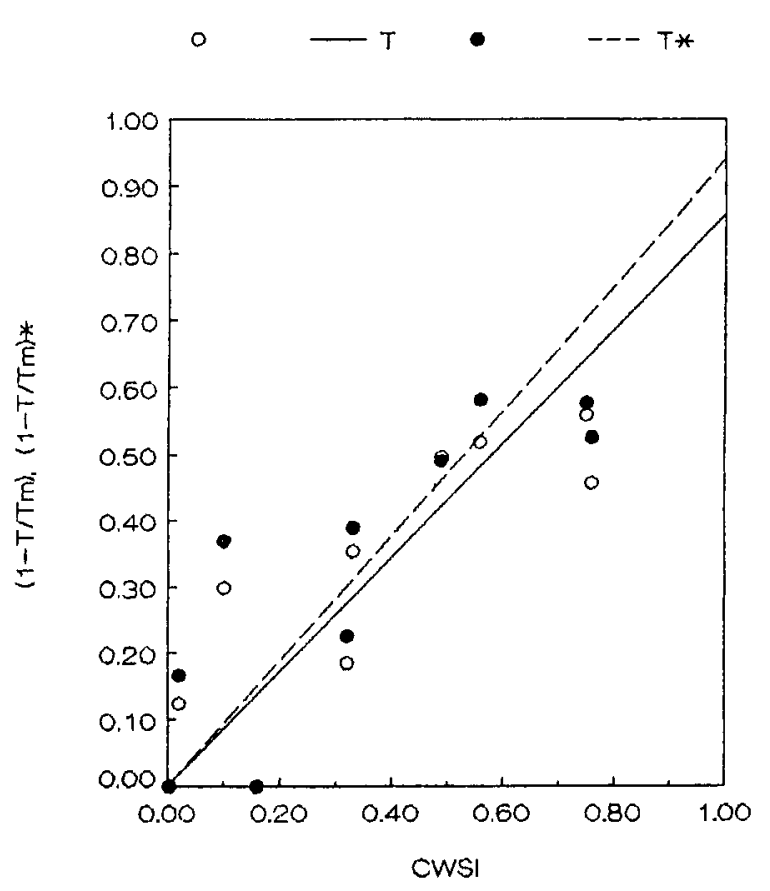

Fig 11. The relationships between $(1-\mathrm{T} / \mathrm{Tm})$, corrected $(1-$ $\mathrm{T} / \mathrm{Tm})\left({ }^{*}\right)$ and CWSI.

$$
\begin{aligned}
& \text { CWSI }=1.06(1-\mathrm{T} / \mathrm{Tm})^{\star} \\
& \mathrm{df}=8, R^{2}=0.891, P<0.01
\end{aligned}
$$

The eqs [22] and [23] indicated that for the duration of irrigation treatments, the obtained results were in accordance with the theoretical analysis of Jackson et al (1981). So, assuming a zero average CWSI for the period before imposition of irrigation treatments, the measured values of average CWSI were multiplied by ETa/ETt $(E T a=$ evapotranspiration for the period of irrigation treatments and $\mathrm{ETt}=$ evapotanspiration for the growing season). The results are corrected CWSI, (CWSIC).

The relationship between CWSIc and (1 ET/ETm) is as follows:

$$
\begin{aligned}
& \text { CWSIc }=0.98(1-\text { ET/ETm }) \\
& \text { df }=9, R^{2}=0.894, P<0.01
\end{aligned}
$$

Now, the coefficient of eq [24] (0.98) is almost 1. The relationships between grain ( $t / h a)$ and aerial dry matter yields (t/ha) and CWSIc by least squares fitting are as follows:

$$
\begin{aligned}
& Y=2.64-2.5 \text { CWSlc } \\
& \mathrm{df}=9, R^{2}=0.92, P<0.01 \\
& Y t=5.60-2.9 \mathrm{CWSI} \\
& \mathrm{df}=9, R^{2}=0.815, P<0.01
\end{aligned}
$$

The relationships between ET and ( $T \mathrm{c}-\mathrm{Ta}$ ) and $(T \mathrm{c}-T \mathrm{c})$ between $13 \mathrm{~h} 00$ and $14 \mathrm{~h} 00$ for cowpea by least squares procedure are as follows:

$$
\begin{aligned}
& \text { ET }=5.36-0.49(T \mathrm{C}-T \mathrm{a}) \\
& \mathrm{df}=174, R^{2}=0.53, P<0.01 \\
& \text { ET }=7.58-0.53\left(T \mathrm{C}-\mathrm{TC}^{*}\right) \\
& \mathrm{df}=174, R^{2}=0.51, P<0.01
\end{aligned}
$$

in which $T C^{*}$ is the canopy temperature $\left({ }^{\circ} \mathrm{C}\right)$ of well-watered plants with no water deficit. The values of 5.36 eq [27] and 7.58 eq [28] may be considered as estimates of seasonal average values of $R \mathrm{n}$ and ETp ( $\mathrm{mm} / \mathrm{day}$ ) respectively. The slopes of eqs [27] and [28] ( $B$ and $B^{\prime}$ ) for cowpea are 0.49 and 0.53 , respectively. The values of $B$ for wheat, short grass and corn were $0.64,0.22$ and $0.66 \mathrm{~mm}$ day $^{-1} \mathrm{~kg}^{-1}$ as reported by Jackson et al (1977) and Seguin and Itier (1983), respectively. Furthermore, the values of $B^{\prime}$ for short grass, potato and sugarbeet were $0.37,0.66$ and $1.62 \mathrm{~mm}$ day-1 $\mathrm{kg}^{-1}$ as reported by Nieuwenhuis et al (1985). Considering the differences in height, root depth and leaf resistance to vapor flow between cowpea and wheat, short grass and corn, the $B$ and $B^{\prime}$ values for cowpea are expected to be greater than those of short grass and smaller than those of corn.

By measuring the $T c, T a$ and $T c *$ by infrared thermometer or remote sensing devices, eqs [27] and (28) may be used to estimate the ET of cowpea in arid or semi-arid conditions.

\section{Application to irrigation scheduling}

Eq [25] may be used with some restriction, to determine the critical level of CWSI for irrigation timing. By considering a $90 \%$ relative grain yield of cowpea, ie, $Y=0.9 \times 2.64=2.38 \mathrm{t} / \mathrm{ha}(10 \%$ permissible grain yield reduction) in eq [25], the seasonal average of CWSI at the time of irrigation should be 0.106 in eq [25].

Soil, plant and atmosphere parameters may be used in irrigation scheduling (Geiser et al, 1982). Therefore, ( $T \mathrm{c}-\mathrm{Ta}$ ) of plant canopy, ${ }^{\circ} \mathrm{C}$, net radiation $(R \mathrm{n}), \mathrm{cal} / \mathrm{cm}^{2} \mathrm{~min}$, relative humidity of air $(\mathrm{RH}), \%$ and relative soil available water in root zone of $120 \mathrm{~cm}$, (AW) between $13 \mathrm{~h} 00$ and $14 \mathrm{~h} 00$ were used in a multiple regression model as follows:

$(T \mathrm{c}-\mathrm{Ta})=15.7 \mathrm{AW}+0.25 \mathrm{RH}+7.77 R \mathrm{n}-5.02$ $R^{2}=0.466$ 
in which $38.4,6.6$ and $1.6 \%$ of variations in ( $T \mathrm{C}-$ $\mathrm{Ta}$ ) were explained by $\mathrm{AW}, \mathrm{RH}$ and $\mathrm{Rn}$ respectively. Therefore, the results indicated that this model was not sensitive to $R$ n so that it may be omitted and the model would be as follows:

$$
\begin{aligned}
& (T \mathrm{c}-\mathrm{Ta})=-16.4 \mathrm{AW}+0.26 \mathrm{RH}+2.86 \\
& R^{2}=0.45, P<0.01
\end{aligned}
$$

By considering the critical AW for cowpea as 0.4 (Sepaskhah and llampoor, 1995) in eq [30] the critical $(T c-T a)$ was obtained as follows:

$$
(T \mathrm{c}-\mathrm{Ta})_{\mathrm{c}}=0.26 \mathrm{RH}-3.71
$$

By measuring $\mathrm{RH}$ and $(\mathrm{Tc}-\mathrm{Ta}$ ) between $13 \mathrm{~h} 00$ and $14 \mathrm{~h} 00$, the same as CWSI, irrigation timing of cowpea may be determined. By substitution of the measured $\mathrm{RH}$ in eq [31] the $(T \mathrm{C}-\mathrm{Ta})_{\mathrm{C}}$ is calculated. If the measured $(T C-T a)$ is equal to or greater than the $(T \mathrm{C}-T \mathrm{a})_{\mathrm{C}}$, it is time to irrigate. It should be noticed that eq [31] is not identical to eq [8]. The optimum CWSI for irrigation timing was 0.106 , therefore, the $(T C-T a)_{C}$ should be greater than $(T C-T a)_{1}$. However, wind velocity and net radiation variations may limit the application of this technique.

\section{CONCLUSION}

In general, the crop water use is rather high due to the climatic conditions of the region. The maximum grain and aerial dry matter of cowpea were produced with $I=97.0 \mathrm{~cm}, \mathrm{ET}=102.1 \mathrm{~cm}$, and $I=102.2 \mathrm{~cm}$ and $\mathrm{ET}=91.4 \mathrm{~cm}$, respectively. The water sensitivity factor for grain production of cowpea was 1.01 and may be used for yield prediction in response to crop water use. It was concluded that water stress is acting separately on dry matter and grain productions. Furthermore, harvest index was non-linearly dependent on seasonal transpiration. Quadratic production functions (yield vs irrigation water and/or ET) for grain and aerial dry matter of cowpea were obtained. At the early vegetative stage of plant growth, by deficit irrigation, the soil water storage may be used by plant. The production function (eq [10]) may be used in irrigation water management for economical production, ie, $90 \%$ of maximum production may be obtained by $71.8 \mathrm{~cm}$ of irrigation water equivalent to $74 \%$ of the maximum required irrigation water. By $k$ value $(0.041$ $\mathrm{mb}$ ), eq [19], environmental parameters, and seasonal transpiration of cowpea, its grain yield could be predicted.
It was also concluded that different lower baseline may be attributed to different cultivars of a species. Irrigation timing of cowpea, with some restrictions, may be determined by CWSI of 0.106 measured between $13 \mathrm{~h} 00$ and $14 \mathrm{~h} 00$.

\section{ACKNOWLEDGMENTS}

This research was supported in part by project $\mathrm{n}^{\circ} 66$ Ag-463-240 of Shiraz University Research Council.

\section{REFERENCES}

Abdul-Jabbar AS, Lugg DG, Sammis TW, Gay LW (1985) Relationships between crop water stress index and alfalfa yield and evapotranspiration. Trans ASAE 28, 454-461

Arkley RJ (1963) Relationships between plant growth and transpiration. Hilgardia 34, 559-583

Bierhuizen JF, Slatyer RO (1965) Effect of atmospheric concentration of water vapor and $\mathrm{CO}_{2}$ in determining transpiration, photosynthesis relationships of cotton leaves. Agric Meteorol 2, 259-270

de Wit CT (1958) Transpiration and crop yields. Versl Landbouwk Onderz 64.6 Inst of Biol and Chem Res on Field Crops and Herbage, Wageningen, The Netherlands

Doorenbos J, Kassam AH (1979) Yield response to water. FAO Irrigation and Drainage Paper 33, FAO, Rome, Italy, $193 \mathrm{p}$

Doorenbos J, Pruitt WO (1977) Crop water requirements. FAO Irrigation and Drainage Paper, $24 \mathrm{R}$, Rome, Italy, $144 \mathrm{p}$

Geiser KM, Slack DC, Allred ER, Stange KW (1982) Irrigation scheduling using crop canopy - air temperature difference. Trans ASAE 25, 689-694

Hanks RJ (1983) Yield and water-used relationships: an overview. P 393-411. In: Limitations to Efficient Water Use in Crop Production (HM Taylor et al, eds). Am Soc Agron, Madison, WI

Hanks RJ, Keller J, Rasmussen VP, Wilson GD (1976) Line source sprinkler for continuous variable irrigation-crop production studies. Soil Sci Soc Am J 40, 426-429

Howell TA, Hatfield JL, Yamada H, Davis KR (1984) Evaluation of cotton canopy temperature to detect crop water stress. Trans ASAE 27, 84-88

Idso SB (1982) Non-water stressed base line: a key to measuring and interpreting plant water stress. Agric Meteorol 27, 59-70

Idso SB, Jackson RD, Pinter PJ Jr, Reginato RJ, Hatfield JL (1981) Normalizing the stress-degree day parameter for environmental variability. Agric Meteorol 24, 45-55 
Jackson RD, Idso SB, Reginato RJ, Pinter PJ Jr (1981) Canopy temperature as a crop water stress indicator. Water Resour Res 17, 1133-1138

Jackson RD, Reginato RJ, Idso SB (1977) Wheat canopy temperature: a practical tool for evaluating water requirements. Water Resour Res 13, 651-656

Nieuwenhuis GJA, Smidt EH, Thunnissen HAM (1985) Estimation of regional evapotranspiration of arable crops from thermal infrared images. Int $J$ Rem Sens $6,1319-1334$

Pinter PJ Jr, Reginato RJ (1982) A thermal infrared technique for monitoring cotton water stress and scheduling irrigation. Trans ASAE 25, 1651-1655

Robert J, Reginato RJ, Howe J (1985) Irrigation scheduling using indicators. J Irrig Drain Eng 111, 125133

Seguin B, Itier B (1983) Using midday surface temperature to estimate daily evaporation from satellite thermal IR data. Int J Rem Sens 4, 371-383

Sepaskhah AR, Kashefipour SM (1994) Relationships between leaf water potential, CWSI, yield and fruit quality of sweet lime under drip irrigation. Agric Water Manag 25, 13-22
Sepaskhah AR, llampoor S (1995) Effects of soil moisture stress on evapotranspiration partitioning. Agric Water Manag (in press)

Sepaskhah AR, Nazemossadat SMJ, KamgarHaghighi AA (1987) Water stress of sugarbeet as related to leaf and canopy temperature and to leaf water content. Iran Agric Res 6, 29-43

Sepaskhah AR, Nazemossadat SMJ, KamgarHaghighi AA (1988) Estimation of upper limit canopy to air temperature differential for sugarbeet using indirect measurement of turgor potential. Iran Agric Res 7, 107-122

Stegman EC (1989) Soybean yields as influenced by timing of ET deficits. Trans ASAE 32, 551-557

Stegman EC, Soderlund MG (1989) Irrigation scheduling of spring wheat using infrared thermometry. Inter Winter Meeting of the ASAE, New Orleans, Paper $n^{\circ}$ 89-2688

Tanner CB (1981) Transpiration efficiency of potato. Agron J 55, 210-211

Tanner CB, Sinclair TR (1983) Efficient water use in crop production: research or research, p 1-27, In: Limitations to Efficient Water Use in Crop Production (HM Taylor et al, eds), Am Soc Agron, Madison, WI 